\title{
REVIEW OF ALUMINA IN ADSORPTION PROCESSES FOR EMERG- ING POLLUTANTS
}

Simón Yobanny Reyes-López ${ }^{1} \rrbracket$, Karem Arely Aguirre-Terrazas ${ }^{1}$, Jonatan Torres-Pérez ${ }^{1}$, Medellín-Castillo Nahúm ${ }^{2}$ and Álvaro de Jesús Ruíz-Baltazar ${ }^{3}$

${ }^{1}$ Instituto de Ciencias Biomédicas, Universidad Autónoma de Ciudad Juárez, Envolvente del PRONAF y Estocolmo s/n, Ciudad Juárez, Chihuahua, México

${ }^{2}$ Universidad Autónoma de San Luis Potosí, Dr. Manuel Nava \#8, Zona Universitaria, San Luis Potosí S.L.P, México. Tel.: (52) 48173381

${ }^{3}$ CONACYT-Centro de Física Aplicada y Tecnología Avanzada, Universidad Nacional Autónoma de México, Boulevard Juriquilla 3001, Juriquilla las Mesas, Querétaro, QRO, México

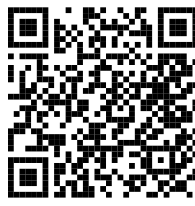

Juriquilla 3001, Juriquilla las Mesas, Querétaro, QRO, México

Received 1 April 2021

Accepted 14 April 2021

Published 30 April 2021

Corresponding Author

Simón Yobanny Reyes-López, simo

n.reyes@uacj.mx

DOI 10.29121/

granthaalayah.v9.i4.2021.3846

Funding: This research received no specific grant from any funding agency in the public, commercial, or not-for-profit sectors.

Copyright: (C) 2021 The Author(s). This is an open access article distributed under the terms of the Creative Commons Attribution License, which permits unrestricted use, distribution, and reproduction in any medium, provided the original author and source are credited.

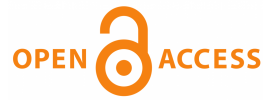

\section{ABSTRACT}

Water pollution can be found in the oceans, seas, rivers and lakes which can be taken as organic pollutants or better known as emerging pollutants. Emerging pollutants (EP's) are chemical substances that persist in the environment, these molecules are bioaccumulated in the food chain causing risks and adverse effects for human health and the environment. EP's are not monitored and they are discharged as effluents indiscriminately, for this reason is important to improve water treatment by the application of advanced techniques as adsorption. Adsorbents like alumina are known for their large surface area, high mechanical properties and good resistivity to thermal degradation. Aluminum oxide or alumina (Al203) is a solid white ceramic material which has been considered an efficient adsorbent for EP's removal as advanced water treatment.

Keywords: Pollution, Treatment, Adsorption, Effluents, Emerging Pollutants, Alumina

\section{INTRODUCTION}

Water is a resource distributed throughout the world, it can be found in oceans, rivers and lakes, that is considered as surface water, or can be found in aquifers (groundwater). The availability of this resource is related to caring and water quality, that ensures that the water is enough for its intended use "Estadísticas del agua en México" (2014). Water pollution is very interesting topic in the field of environmental research, the location of effluents from specific sources must be known because it can cause changes in aquatic environment Fumey et al. (2014). Pollution can be classified into two types: inorganic and organic pollution. The inorganic compounds found in 
water usually come from two different sources, (natural and anthropogenic), among them, salts, metalloids and metals are considered in this kind of compounds and they are highly soluble. Metals enter in water as a result of the aging of soil and rocks, volcanic eruptions, and a variety of anthropogenic activities related to mining, processing, and use of metals and / or substances containing metallic pollutants Karageorgis et al. (2003).

Water pollution poses a threat to human health and ecosystems, leading to the depletion of clean water resources and trace organic pollutants become a major environmental problem Petrie et al. (2015); Schwarzenbach et al. (2006). In the aquatic environment, including drinking water sources and water bodies, organic micropollutants are present in trace concentrations ranging from ng L ${ }^{-1}$ to $\mu \mathrm{g} \mathrm{L}^{-1}$ Gracia-Lor et al. (2011); Hughes et al. (2013); Joss et al. (2008). The most dangerous sources of water pollution even in small concentrations are pesticides, dyes and pharmaceutical products which are considered also EP's Rivera-Utrilla et al. (2013).

\subsection{EMERGING POLLUTANTS}

EP's include substances such as pharmaceutical compounds and personal care products, pesticides and hormones which have adverse effects on the endocrine system of humans and animals Ruhí et al. (2016). The number of substances that constitute the EP's is large and continues to increase with the identification of chemicals that are part of this group Richardson and Ternes (2014). However, the list of incidence and risk contribution for most of these pollutants is not yet available. Due to the analytical challenge of monitoring the large number of substances is difficult to predict the effects on human health and other living beings Damià (2003). On the other hand, it has been shown that a large amount of EP's can change the endocrine system as described above, block or interfere with the hormonal function of the body, cause feminization and hermaphroditism, decrease fertility, decrease the efficiency of mating, and even it can increase the incidence of different types of cancer Clemente et al. (2013). Among the emerging pollutants that usually cause more problems in water treatment, the pharmaceutical products are one of the most used, because of that they are produced at large scale. Various drugs have low metabolization (5-10 $\%$ ) and low absorption rates in the organisms that consume them, leading to high amounts of drug residuals accumulated in soil or water, causing serious pollution problem Daughton and Ternes (1999).

Natural attenuation and conventional treatments are not capable to remove EP's from waste, surface and drinking water Huerta et al. (2015). Likewise, these substances do not have any regulation for their disposal. Nowadays, indiscriminate discharges of these are made increasing the aquatic bodies pollution. The EP's most studied because of the adverse effects to ecosystems are pharmaceutical products, detergents, fragrances, personal care products and illicit drugs Zacarías et al. (2017). Therefore, it is considered important to know the definition of each type of emerging pollutant, for example: 
A pesticide can be defined as any substance or mixture of substances that can prevent, destroy, repel or mitigate any pests such as insects, mites, nematodes, weeds, rats, etc. Zhang et al. (2011). Pest control was practiced as a mechanical approach in 18th century. Before the synthetic pesticides period, natural compounds such as arsenicals and fluorosilicates were used for pest control Yedla and Dikshit (2005). The synthetic pesticides period began in 1874, when DDT (Dichlorodiphenyltrichloroethane) was synthesized by the first time. Pesticides are very complex in structure and they are well known for their stable and non-degradable nature in the environment. The utility of pesticides in the world was found in agriculture, grain storage, soil conditioning, public health, and building construction Yedla and Dikshit (2005). Over the past 50 years, the number of available pesticides, the variety of their applications and the volume of active ingredients used has grown tremendously. It is estimated that more than 1500 chemical pesticides have been produced and up to 8000 individual formulations are available for specific applications Bansal and Goyal (2005). The sources of pesticides in the aquatic environment are principally the wastes discharges from pesticide production and formulation industry. Surface and groundwater pollution occurs through pesticide leaching, which has been documented by many researchers Yedla and Dikshit (2005).

Pharmaceutical compounds are synthetic or natural chemicals found in prescription drugs, free sell and veterinary drugs, as well as containing active ingredients that are designed to cause pharmacological effects and significantly benefit society "Pharmaceuticals in drinking-water" (n.d.). Pharmaceutical compounds have been recognized as a dangerous class of organic pollutants due to their extensive use and longterm effects towards the aquatic environment Ashfaq et al. (2016).

Dyes and pigments are chemical substances or compounds, natural or synthetic, that change the color of another substance or compound when they are applied on it. The use of dyes has been an activity of economic importance since ancient times, likewise the search for new dyes has not ceased over time. The first dyes were natural, obtained from plants, animals and fungi; as far as synthetic dyes are concerned, they are manufactured by technological synthesis, and they emerged in the 19th century with the development of organic chemistry mainly from fossil sources Cardon (2010). Most dyes are stable in air and under light; therefore, dyes in wastewater do not respond to ordinary biological or chemical degradation Hasan et al. (2008). Dyes affect the photosynthetic capacity of aquatic plants by restricting the penetration of sunlight due to their color Rane et al. (2014). The structural varieties of dyes can fall into the cationic, non-ionic or anionic types. Among these types, anionic dyes include direct, acidic, and reactive dyes Mishra and Tripathy (1993). Acid bright dyes and water-soluble acid dyes are the most problematic dyes, they tend to easily pass-through conventional treatment systems in unaffected way Willmott et al. (1998). More than 100,000 commercial dyes are known with a production amount of more than 700,000 tons per year worldwide Sen et al. (2011). Acid dyes are soluble in water and appear with acid groups in their molecular structures. Acid dyes 
can be grouped into three classes including azo, anthraquinone, and triarylmethane. Among these different acid dyes, azo dyes are the main class with a great variety of colors Kordouli et al. (2015).

\subsection{WATER TREATMENT}

EP's need to be removed from the water to improve the environmental quality, the water treatment methods that are conducted by chemical or biological reactions are known as unit processes. Today, the unit's functions combine to provide multiple levels of treatment and they are referred as preliminary treatment, primary, advanced primary, secondary (without or with nutrient removal), and advanced (or tertiary) treatment \&amp; Metcalf and Eddy (2003) (Fig. 1). Today, various treatment processes are used for the removal of organic molecules from aqueous solutions including: precipitation, ultrafiltration, ion exchange, phytoextraction, electrodialysis, and reverse osmosis. In primary treatment, physical operations are usually carried out by sedimentation to remove floating and sediment substances in wastewater. For advanced primary treatments, chemicals are added to improve suspended and dissolved solids removal. The main physicochemical processes that can be included in the primary treatment are the following: sedimentation, flotation, coagulationflocculation and filtration \&amp; Metcalf and Eddy (2003).

In secondary water treatment, biological and chemical processes are used to eliminate most of the organic matter, which constitutes a series of important biological processes for the wastewater treatment that usually use microorganisms (bacteria). To eliminate biodegradable organic matter, colloidal and dissolved, as well as the elimination of compounds that contain nutrient elements ( $\mathrm{N}$ and $\mathrm{P}$ ) can be used electrocoagulation, bacterial beds, active sludge, green filters, anaerobic digestion and electro-oxidation \&amp; Metcalf and Eddy (2003). In advanced treatment, additional combinations of unit operations and processes are used to remove residual suspended solids, organic matter, and other constituents that are not significantly reduced by conventional secondary treatment such as phosphorus and nitrogen. The advanced processes have properties of biological or physicochemical nature, the unit process is the most used in physicochemical treatments. At the initial stage, coagulation-flocculation and decantation are carried out. Other processes used as tertiary treatments are ion exchange resins, activated carbon adsorption, ultrafiltration, reverse osmosis, electro-disinfection and ceramic membranes \&amp; Metcalf and Eddy (2003); adsorption is the most economical of the aforementioned.

Adsorption is an economical and efficient technology that produces high quality water Lesmana et al. (2009), it has been considered an effective alternative for wastewater treatment and it has been used for the elimination of hazardous organic and inorganic pollutants present in the effluent An, Mcbean, et al. (2016); An, Yang, et al. (2016); Kurtan et al. (2016); X. Liu et al. (2016). Adsorption consists in the accumulation of a substance between two phases (liquid-solid and gas-solid), that occurs as a result of unsaturated and unbalanced molecular forces which occur on each solid 


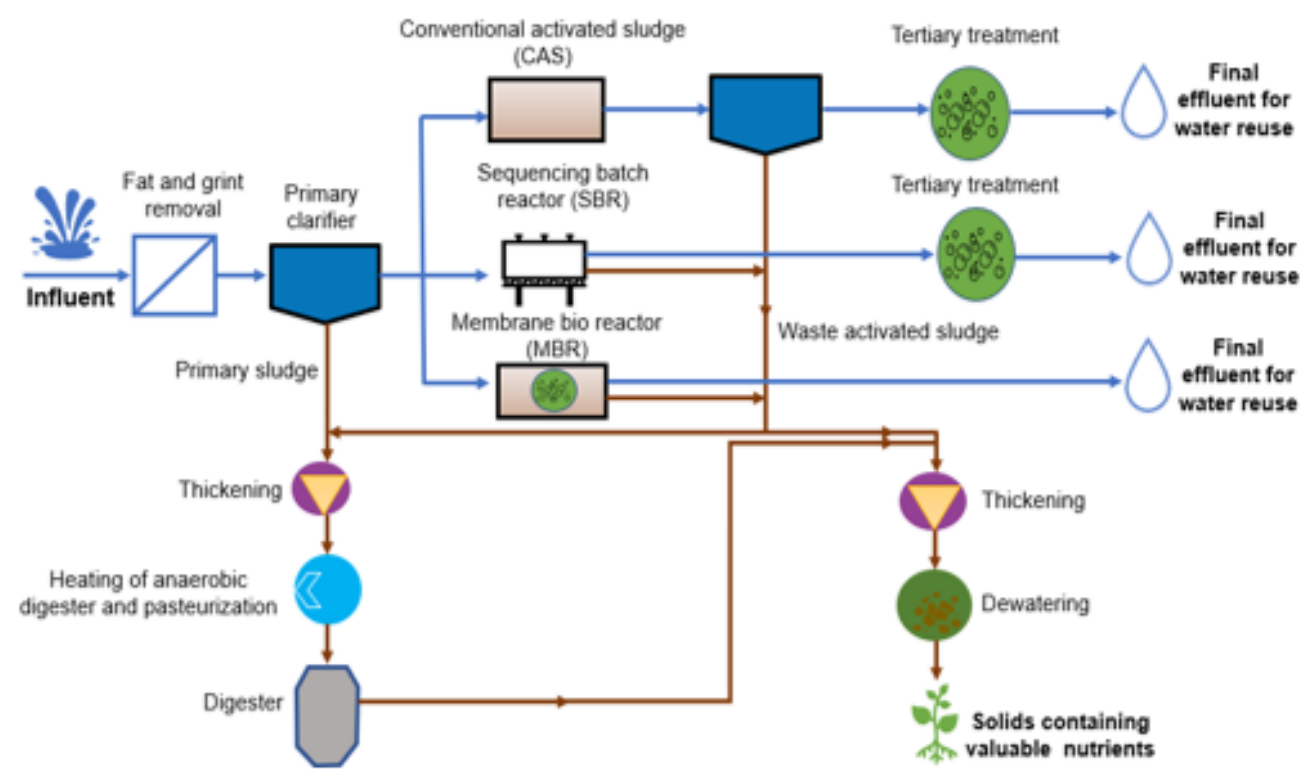

Figure 1 Wastewater treatment diagram

surface. Thus, when a solid surface is in contact with a liquid or gas, there is an interaction between the fields of forces on the surface with the adsorbate. Depending on the nature of the involved forces, there are two types of adsorption: physical and chemical adsorption. In the case of physical adsorption, the adsorbate is attached to the surface by Van Der Walls forces that are relatively weak, these forces are like the molecular forces of cohesion and participate in the condensation of vapors in liquid. On the other hand, chemistry involves the exchange of electrons between adsorbate molecules and the surface of the adsorbent, resulting in a chemical reaction Bansal and Goyal (2005). The molecule that is accumulated or adsorbed on the interface is called adsorbate, and the solid on which adsorption takes place is the adsorbent Brage (2002).

In adsorption, molecules or ions are removed from aqueous solution by adsorption on solid surfaces. This process is characterized by having active sites in energy, as well as interaction with solutes in the adjacent aqueous phase due to their specific electronic and spatial properties. Generally, the active sites have different energies, and the surface is energetically heterogeneous. By changing the properties of the liquid phase $(\mathrm{pH}$, concentration, temperature), the adsorbed species are usually released from the surface and transferred back to the liquid phase, a process known as desorption Eckhard (2012). Within the sorption processes, some materials are investigated to be efficient in the process; materials can be defined an element that can be transformed, and it is possible to group it, scientifically. A material can be defined as any solid composed of discrete particles that is or will be used to manufacture products that improve living conditions. Its properties are defined by the 
state of organization of its atoms, which, theoretically, do not change in shape, size and weight when they are processed Mercier et al. (2002).

Materials can be generally classified according to their main properties and characteristics: metallic, polymeric and ceramic materials Smith and Hashemi (2006).

- Metals: Metallic materials refer to inorganic substances composed mainly of metallic elements such as copper, aluminum, iron, magnesium, nickel, titanium, zinc, tin, lead and alloys such as brass, steel and bronze. However, they can contain non-metallic elements, such as carbon, oxygen and nitrogen. All these materials have characteristic properties, such as brightness and high thermal and electrical conductivity, they are also ductile, and some of them have good magnetic properties Smith and Hashemi (2006).

- Polymers: The term polymer refers to molecules formed from various building blocks, which are called monomers, these types of blocks are generally linked by covalent bonds. The prefix "poly" from the Greek word "many", while the Greek prefix "mono" means "unique" and refers to a single block. In the synthesis of many polymers, the monomers are linked together in the same way to form a single chain consisting of repeating, covalently connected units. There is no definitive limit on the number of repeating units required to meet the definition of the polymer Sebastian et al. (2017).

- Compounds: It can be defined as the integration of two or more materials to form a new one. In such a way that each component retains its properties, and the resulting component has properties of both materials. They are heterogeneous materials since they have a discrete interface that separates them Smith and Hashemi (2006). Both the matrix and the charge can be of different nature such as: metallic, inorganic (metallic and non-metallic oxides), organic (polymers) material, among other combinations. This makes it possible to obtain metal-metal, metal-inorganic or inorganic-metal, organic-inorganic or organicmetal compounds Naganoma and Zagawa (2002).

- Ceramics: Ceramics are non-metallic inorganic materials, which are formed by metallic and non-metallic elements that are linked primarily by ionic and / or covalent bonds. The chemical compositions of ceramic materials can vary considerably, from simple compounds to mixtures of many complex linked phases Smith (2009). In general, ceramic materials can be classified into two groups: traditional ceramic materials and ceramic materials for specific use. Traditional ceramic materials are normally made up of three basic components: clay, silica and feldspar. Examples of traditional ceramics are bricks, ceramics for specific use, are made up of pure or almost pure compounds such as aluminum oxide $\left(\mathrm{Al}_{2} \mathrm{O}_{3}\right)$, silicon carbide $(\mathrm{SiC})$, and silicon nitride $\left(\mathrm{Si}_{3} \mathrm{~N}_{4}\right)$. 


\subsection{ALUMINA}

Adsorbents such as alumina are known for their large surface area, high mechanical properties, and good resistivity to thermal degradation. Aluminum oxide or alumina $\left(\mathrm{Al}_{2} \mathrm{O}_{3}\right)$ is a solid white ceramic material, it has a molecular weight of $101.96 \mathrm{~g} / \mathrm{mol}$, a density of $3.9 \mathrm{~g} / \mathrm{mL}$, a melting and boiling point of 2320 and $3600{ }^{\circ} \mathrm{C}$ respectively. It is also insoluble in water and partially soluble in ethanol Sastre et al. (2004). Among its most important properties are the hardness of 18 to $20 \mathrm{GPa}$, elastic modulus of 300 to $400 \mathrm{GPa}$, thermal conductivity equal to $30 \mathrm{~W} / \mathrm{mK}$, it is an excellent electrical insulator, it has good resistance to thermal fatigue $4-9 \times 10^{-6} /{ }^{\circ} \mathrm{C}$ and excellent optical transparency Ashby and Jones (2008). Additionally, alumina is chemically stable, it is considered inert, and it does not oxidize or corrode easily or react within biological systems. Its resistance to fracture is low (2-4 $\mathrm{MPa}^{1 / 2}$ ), to be used it must be compacted with a high density, with an average size close to $4 \mu \mathrm{m}$ per gram and high purity $\geq 99.5 \%$ Sastre et al. (2004). Alumina $\left(\mathrm{Al}_{2} \mathrm{O}_{3}\right)$ is a crystalline ceramic that possesses polymorphism with metastable structures $(\omega, \kappa, \delta, \theta$ and $\gamma$ phases) Boumaza et al. (2009); Khang et al. (2009). Alumina is ceramic with a hexagonal crystal lattice according to Figure 1 . The oxygen and aluminum define a hexagonal close packed structure, aluminum cations occupy $2 / 3$ of the octahedral sites in the hcp lattice.
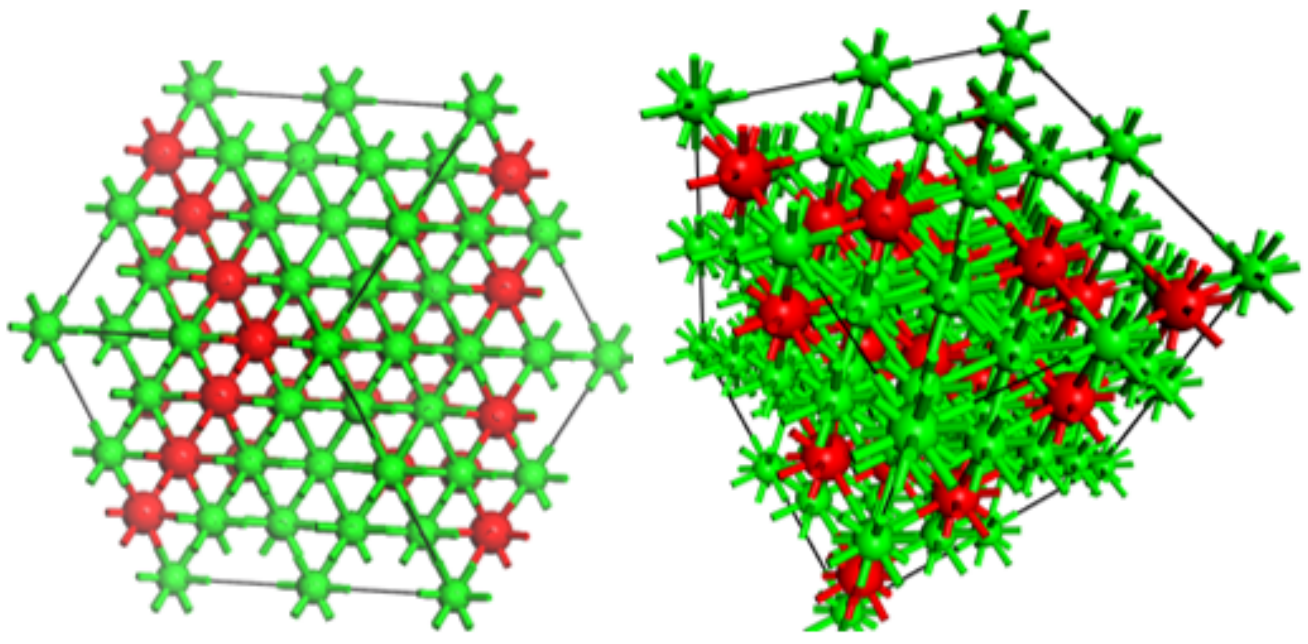

Figure 2 Alumina structural unit cell.

Calcined aluminas are generally classified into three categories according to their chemical composition, as well as their sodium content as total impurities.

First category: Normal calcined alumina

It has a sodium oxide content greater than $0.1 \%$, and $99-99.5 \%$ of aluminum oxide.

Second category: Low sodium or thermally reactive alumina 
It has a sodium oxide content less than $0.1 \%$, and around $99.7 \%$ aluminum oxide. Third Category: High Purity Calcined Alumina

It has an aluminum oxide $99.9 \%$ purity, most of these aluminas are manufactured from aluminum salts with high purity (chlorides, sulfates, nitrates, ammonium alum), oxidation of aluminum at high pressure or metallic aluminum López and Y (2006).

\subsection{ALUMINA AS AN ADSORBENT}

Due to the properties that alumina possesses, it is used as an adsorbent, Chu in 2019 Chu et al. (2019) mention that the alumina nanoparticles were manufactured by the solvothermal method, the alumina nanoparticles obtained had sharp peaks with high intensity at $2 \theta=38^{\circ}$ and $67^{\circ}$ indicating high crystallinity of alumina. In its gamma phase, crystalline alumina has XRD peaks at $46^{\circ}$ and $61^{\circ}$; as well as infrared spectroscopy bands at $3657.04,3550.95$ and $3622.32 \mathrm{~cm}^{-1}$ for the stretching vibration $-\mathrm{OH}$, the bands obtained at 1031.92, 520.78 and $426.27 \mathrm{~cm}^{-1}$ are corresponding to the $\mathrm{Al}-\mathrm{O}$ bending vibration of the $\mathrm{Al}-\mathrm{OH}$ group, finally, the signals between $1000 \mathrm{~cm}^{-1}, 981.77 \mathrm{~cm}^{-1}$ and $520.78 \mathrm{~cm}^{-1}$ confirmed the bending vibration of the Al-O bond. The particle size is in the range of 30 to $40 \mathrm{~nm}$, the specific surface area was around $221.3 \mathrm{~m}^{2} / \mathrm{g}$. The synthesized material with a modification was made with an anionic surfactant (sodium dodecyl sulfate, SDS) where the elimination of the cationic dye, Rhodamine $\mathrm{B}(\mathrm{RhB})$ was investigated. The modification of nanoalumina was carried out at a low pH of 4 and 5, with a high ionic strength which significantly increased the removal efficiency of $\mathrm{RhB}$ and it was found that the optimal adsorption conditions of contact time, $\mathrm{pH}$ and adsorbent doses for $\mathrm{RhB}$ removal using SDS-modified nanoalumina (SMNA) were $120 \mathrm{~min}$, at pH 4 and $5 \mathrm{mg} / \mathrm{mL}$, respectively. The removal of RhB using SMNA reached a removal efficiency of $100 \%$ (Table 1). After four cycles of adsorbent regeneration, the RhB removal efficiency using SMNA was greater than $86 \%$, reaching an adsorption capacity of $165 \mathrm{mg} / \mathrm{g}$.

Alumina has also been used for the removal of methylene blue, Ebadollahzadeh and Zabihi in 2020 Ebadollahzadeh and Zabihi (2020) managed to synthesize magnetic alumina, the XRD results showed that the strongest and sharpest peaks appeared on the pattern of functionalized magnetic gamma-alumina is in $2 \theta=$ $15-80^{\circ}$. Bands around $720-931 \mathrm{~cm}^{-1}$ corresponded to Al-O of gamma-alumina. The band presented at the wavelength of $1633 \mathrm{~cm}^{-1}$ is related to the carbon-oxygen bond that is assigned to the stretching vibration of $\mathrm{C}=0$ in asymmetric $\mathrm{COO}$, due to the presence of functional groups placed when applying EDTA as chemical agent. The weak band at $1400 \mathrm{~cm}^{-1}$ related to the $\mathrm{C}-\mathrm{N}$ bond appears poorly only on the alumina adsorbent due to impregnation by EDTA. The bands around 3300-3400 $\mathrm{cm}^{-1}$ correspond to the symmetric and asymmetric vibrations of the $\mathrm{N}-\mathrm{H}$ and $-\mathrm{OH}$ groups, respectively, which overlap each other. The findings revealed that the experimental data were consistent with the Freundlich model, with the maximum adsorption capacity being $196.08 \mathrm{mg} / \mathrm{g}$ for methylene blue. The pseudo-second order kinetics with the highest correlation coefficient indicated a better fit with the 
adsorption of methylene blue. The regeneration of the magnetic adsorbent was also investigated in the competitive adsorption for six cycles, which showed that the prepared adsorbent can be used for real applications.

Another dye that has been removed with alumina is Orange G, Banerjee and collaborators in 2017 Banerjee et al. (2017) studied the synthesis and application of alumina nanoparticles synthetizing by the sol gel technique and it was found that the particle size was in the range of 30-35 nm this for the removal of the aforementioned dye from aqueous solutions. The properties of the synthesized nanoparticles show a prominent band at $3457 \mathrm{~cm}^{-1}$ which is attributed to the stretching vibration of the -OH group of the Al-OH structure and another band at $1629 \mathrm{~cm}^{-1}$, which is attributed to the physical adsorption of water molecules. The presence of a broad pattern that extends in a range of $400-1000 \mathrm{~cm}^{-1}$ corroborates the formation of alumina in the gamma phase. The absorption bands at 911,804 , and $637 \mathrm{~cm}^{-1}$ correspond to asymmetric stretch, symmetric stretch, and bending vibration of the Al-O-Al bond, respectively. After the sorption of the dye, it can be clearly noticed there was a slight change in the positions of the bands. It was found that the band of maximum intensity at $3457 \mathrm{~cm}^{-1}$ was slightly reduced and a small change in the position of the peak was observed in the absorption band at $1000-400 \mathrm{~cm}^{-1}$. This indicates that the dye ions most likely interacted with the $\mathrm{Al}-\mathrm{OH}$ and $\mathrm{Al}-\mathrm{O}$ groups present on the adsorbent surface. The four characteristic reflections at $2 \theta=32,37.4,45.2$ and $67.5^{\circ}$ with the corresponding reflection planes of 220,311, 400 and 440 reveal the formation of the gamma species. The TEM image shows that the alumina particles were in an agglomerated state, furthermore, the image also showed that the particle sizes were in a nanorange with the majority being $30-40 \mathrm{~nm}$. The micrograph also verified that the particle size existed in the nanoscale range. The estimated specific surface area was found to be greater than $125 \mathrm{~m}^{2} / \mathrm{g}$. The pore sizes, approximately $90 \%$ were in the mesoporous range (diameters $2-50 \mathrm{~nm}$ ) and the remainder of $10 \%$ were in the microporous range $(<2 \mathrm{~nm})$. The $\mathrm{pH}_{Z P C}$ of the alumina nanoparticles was found to be 7.4. Likewise, the effect of several important parameters on the elimination of the dye was examined and it was found that the adsorption was highly dependent on $\mathrm{pH}$ and obtaining an elimination of $98.4 \%$. The kinetic results showed that the sorption process was described by a pseudo second order model. The mechanism of the adsorption process was also interpreted with the help of diffusion models and the results showed that external diffusion governed the general sorption process. Langmuir's model yielded a good fit for the experimental data with high adsorption capacity $\left(93.3 \mathrm{mg} / \mathrm{g}\right.$ at $\left.303^{\circ} \mathrm{K}\right)$. The evaluated thermodynamic parameters $\Delta \mathrm{G}^{\circ}, \Delta \mathrm{H}$ ${ }^{\circ}$ and $\Delta S^{\circ}$, proposed that the adsorption was spontaneous, feasible and exothermic under the investigated conditions. Desorption experiments confirmed that the spent adsorbent can be successfully regenerated and can be efficiently reused for up to four successive cycles with almost the same sorption capacity, reducing the cost of treatment. The adsorption performance of alumina nanoparticles was also tested using real wastewater and the results indicated that nano-alumina is also competent for 
treating multisolute systems.

Wawrzkiewicz and collaborators in 2015 Wawrzkiewicz et al. (2015) mention that one cause of colorants being found in effluents is due to the fact that the textile, paper, plastic, leather, food and cosmetic industries do not give adequate treatment to their wastewater, which is why they investigated removal by adsorption of acidic (CI Acid Orange 7, A07), reactive (CI Reactive Black 5, RB5) and direct (CI Direct Blue 71, DB71) dyes from aqueous solutions and wastewater using a silica-alumina oxide mixture composed of $4 \% \mathrm{SiO}_{2}$ and $96 \% \mathrm{Al}_{2} \mathrm{O}_{3}$ (SA96). The kinetic studies revealed that with the increase of the initial dye concentration from 10 to $30 \mathrm{mg} / \mathrm{L}$ and the contact time from 1 to $240 \mathrm{~min}$, the sorption capacities (qt) increased and the adsorption equilibrium was observed for A07 and RB5 after $180 \mathrm{~min}$ and $240 \mathrm{~min}$ for DB71. The experimental data fit better to the Langmuir isotherm model than to the Freundlich one and the monolayer sorption capacities $\left(\mathrm{q}_{0}\right)$ were found to be 41.4, 47.1 and 49.2 $\mathrm{mg} / \mathrm{g}$ for A07, RB5 and DB71, respectively.

Just as alumina has been used for the removal of colorants, it has also been used for the removal of pesticides such as lindane, which is a persistent and toxic pesticide in water, Derbalah and collaborators in 2015 Derbalah et al. (2015) carried out a study of manufactured mesoporous alumina nanoparticles (MA-NP) with a large surface to volume ratio, surface active sites, and open channel pores to trap/adsorb molecules such as lindane. The micrographs show the formation of spherical nanoparticles with a uniform particle size (100-250 nm). HRTEM images reveal mesoporous worm-like structures connected to large regions of the alumina nanoparticle domains. The TEM image illustrates a spherical morphology, and agglomeration of the nanoparticles produces gaps between particles without a discernible ordered pore arrangement. The SAXS patterns show two wide reflection scattering peaks within the range of 1.4 $<\mathrm{q}<4.2$; these peaks are characteristic of a hexagonal mesostructure as indicated by the characteristics of the main peaks for hexagonal reflections (100) and (110). The results showed that the maximum adsorption capacity of lindane is $25.54 \mathrm{mg} / \mathrm{g}$ at $20^{\circ} \mathrm{C}$. The material also exhibits high adsorption efficiency (> 80\%) of lindane after 20 cycles, resulting in effective regeneration and reuse characteristics.

Another compound commonly used in the production of pesticides is pnitrophenol, which is why it is important to eliminate this compound from effluents. Zhou and collaborators in 2013 Zhou et al. (2013) carried out a study where they prepared hollow alumina microspheres modified with trisodium citrate. A further observation indicates that the width of the diffraction peaks becomes slightly wider with increasing CTC, which implies the formation of smaller $\mathrm{Al}_{2} \mathrm{O}_{3}$ crystallites, the irregular aggregated particles with rough surface were obtained in the absence of trisodium citrate. An increase in CTC to $0.125 \mathrm{mmol}$ resulted in hollow microspheres with a diameter of approximately $600 \mathrm{~nm}$, and their $50 \mathrm{~nm}$ thick shells composed of loosely connected nanoflakes. A further increase in CTC to $0.25 \mathrm{mmol}$ resulted in hollower structures and smaller pore sizes, when CTC approaches $0.5 \mathrm{mmol}$, the morphology of the sample becomes well-defined microspheres with diameters of 
approximately 2-3 $\mu \mathrm{m}$. Finally, collapsed microspheres appeared when the CTC reached $1 \mathrm{mmol}$. The result of the adsorption of p-nitrophenol in the prepared samples revealed that the pseudo-second order kinetic equation can better describe the adsorption kinetics showing a maximum adsorption capacity of $217.4 \mathrm{mg} / \mathrm{g}$. Furthermore, adsorption isotherm studies indicated that the resulting alumina microspheres are a strong adsorbent for this contaminant.

Since alumina has been widely used for the removal of dyes and pesticides with positive results, an attempt has been made to reproduce the results with other types of compounds such as pharmaceutical compounds. Pham and collaborators in 2019 Pham et al. (2019) investigated the adsorption of molecular oxytetracycline (OTC) of an aqueous solution on surfactant modified alumina (SMA). An anionic surfactant, sodium dodecyl sulfate (SDS), which was used to modify the surface of alumina at high ionic strength. Detailing that the point of zero charge of $\alpha-\mathrm{Al}_{2} \mathrm{O}_{3}$ is approximately 8.0. Some conditions that were effective for OTC removal using SMA were systematically studied, such as contact time, $\mathrm{pH}$, adsorbent dose, and ionic strength. The highest removal efficiency for OTC using SMA was 97\%. Under optimal adsorption conditions, OTC extraction from a real water sample collected from shrimp aquaculture achieved a removal efficiency of $90 \%$. After the adsorbent was regenerated four times, the OTC removal efficiency using SMA was 83\%. The maximum adsorption capacity of OTC on SMA was found to be $143 \mathrm{mg} / \mathrm{g}$. The results obtained demonstrate that the modification of the alumina surface with SDS is important to form a new adsorbent for the removal of tetracycline antibiotics from an aqueous solution.

Nowadays, Dao and collaborators in 2020 Dao et al. (2020) have investigated the synthesis of poly (2-acrylamide-2-methylpropane sulfonic acid) (PAMP) on alumina nanoparticles and for the elimination of the antibiotic ciprofloxacin (CFX) from an aqueous medium, showing a maximum capacity adsorption of approximately 10 $\mathrm{mg} / \mathrm{g}$. The CFX removal application in actual hospital wastewater was greater than $80 \%$. The magnetic resonance spectra can be observed for the signals of a $\mathrm{CH}_{2}$ proton and a $\mathrm{CH}$ proton at 6.3, 6.2 and $5.7 \mathrm{ppm}$ which appeared in the spectra before polymerization but did not appear in the spectra after polymerization. The change in the appearance of the peak before and after polymerization indicated the change in structure or binding in the product. The disappearance of the double bonds in the PAMPs after polymerization indicated that a new saturated substance was formed. Furthermore, the peak of a $\mathrm{CH}$ bond that appeared in the spectra after polymerization indicated the $\mathrm{CH}$ of a saturated group. This implies that the polymerization occurred with high efficiency. The results of the study demonstrate that PAMP on alumina nanoparticles is a promising new material for the removal of antibiotics from wastewater. It is also important to mention that the location of the specific polluted effluents must be known since they can cause a change in the aquatic environments and to be able to give them the appropriate treatment. A continuation a table of alumina used as an adsorbent for different contaminants. 
Table 1 Alumina used in sorption processes for different emerging pollutants.

\begin{tabular}{|c|c|c|c|c|c|}
\hline $\begin{array}{c}\text { Type of } \\
\text { pollutant }\end{array}$ & Material & $\begin{array}{l}\text { Name of the } \\
\text { adsorbed } \\
\text { compound }\end{array}$ & $\begin{array}{c}\% \\
\text { removal }\end{array}$ & $\begin{array}{c}\text { qe } \\
(\mathrm{mg} / \mathrm{g})\end{array}$ & Reference \\
\hline \multirow[t]{15}{*}{ Dyes } & $\begin{array}{c}\text { Nano } \gamma-\mathrm{Al} 203 \\
\text { modified with } \\
\text { surfactant }\end{array}$ & Tartrazine & $\sim 99$ & 165 & Chu et al. (2019) \\
\hline & $\begin{array}{l}\text { Alumina } \\
\text { modified with } \\
\text { surfactant }\end{array}$ & Crystal Violet & 99 & 111.6 & Adak et al. (2005) \\
\hline & $\begin{array}{l}\text { Aluminum } \\
\text { reinforced } \\
\text { polystyrene }\end{array}$ & Amaranth Dye & 96 & - & $\begin{array}{l}\text { Ahmad and Kumar } \\
\text { (2010) }\end{array}$ \\
\hline & $\begin{array}{c}\gamma \text {-alumina } \\
\text { nanoparticles }\end{array}$ & Congo Red & 19 & 655 & $\begin{array}{l}\text { Renuka et al. } \\
\text { (2012) }\end{array}$ \\
\hline & $\begin{array}{l}\text { Mixed Nano } \\
\text { Composites of } \\
\text { Iron Oxide and } \\
\text { Alumina }\end{array}$ & Congo Red & 100 & 498 & $\begin{array}{l}\text { Mahapatra et al. } \\
\text { (2013) }\end{array}$ \\
\hline & Alumina & Malachite green & 93 & 61.35 & $\begin{array}{l}\text { Kannan et al. } \\
\text { (2008) }\end{array}$ \\
\hline & $\begin{array}{l}\text { Silica-alumina } \\
\text { oxide }\end{array}$ & $\begin{array}{c}\text { Reactive Black } 5 \\
\text { C. I. }\end{array}$ & 30 & 6.8 & $\begin{array}{c}\text { Wawrzkiewicz et } \\
\text { al. (2015) }\end{array}$ \\
\hline & $\begin{array}{c}\text { Alumina } \\
\text { nanoparticles }\end{array}$ & Orange G & 98.4 & 93.3 & $\begin{array}{c}\text { Banerjee et al. } \\
\text { (2017) }\end{array}$ \\
\hline & Nanoalumina & Red 120 & $35-80$ & $\begin{array}{l}29 \text { to } \\
35.65\end{array}$ & Nadafi et al. (2014) \\
\hline & $\begin{array}{l}\text { Alumina } \\
\text { modified with } \\
\text { SDS }\end{array}$ & Malachite green & $\sim 80$ & 185 & Das et al. (2009) \\
\hline & $\begin{array}{l}\text { Silica-alumina } \\
\text { oxide }\end{array}$ & $\begin{array}{c}\text { Direct blue } 71 \mathrm{C} \text {. } \\
\text { I. }\end{array}$ & 30 & 6.3 & $\begin{array}{c}\text { Wawrzkiewicz et } \\
\text { al. (2015) }\end{array}$ \\
\hline & $\begin{array}{c}\text { Nano } \gamma-\mathrm{Al}_{2} \mathrm{O}_{3} \\
\text { modified with } \\
\text { surfactant }\end{array}$ & Rhodamine B & 98 & 165 & Chu et al. (2019) \\
\hline & Alumina & Methylene blue & - & 196.08 & $\begin{array}{l}\text { Ebadollahzadeh } \\
\text { and Zabihi (2020) }\end{array}$ \\
\hline & $\begin{array}{c}\text { Alumina/Carbon } \\
\text { Nanotube } \\
\text { Hybrid }\end{array}$ & $\begin{array}{c}\text { Reactive Red } \\
198\end{array}$ & 91.54 & 43.72 & $\begin{array}{l}\text { Malakootian et al. } \\
\qquad \text { (2015) }\end{array}$ \\
\hline & $\begin{array}{c}\text { Silica-alumina } \\
\text { oxide }\end{array}$ & $\begin{array}{c}\text { Acid orange } 7 \mathrm{C} \text {. } \\
\text { I. }\end{array}$ & 30 & 2.9 & $\begin{array}{c}\text { Wawrzkiewicz et } \\
\text { al. (2015) }\end{array}$ \\
\hline
\end{tabular}


Table 2 (Continuation) Alumina used insorption processes for different emerging pollutants.

\begin{tabular}{|c|c|c|c|c|c|}
\hline $\begin{array}{c}\text { Type of } \\
\text { pollutant }\end{array}$ & Material & $\begin{array}{l}\text { Name of the } \\
\text { adsorbed } \\
\text { compound }\end{array}$ & $\begin{array}{c}\% \\
\text { removal }\end{array}$ & qe $(\mathrm{mg} / \mathrm{g})$ & Reference \\
\hline \multirow[t]{15}{*}{ Pesticides } & $\begin{array}{l}\text { Alumina modified } \\
\text { with sodium } \\
\text { dodecyl sulfate }\end{array}$ & Isoproturon & - & $\begin{array}{c}19.15 \text { to } \\
25.31\end{array}$ & $\begin{array}{c}\text { Gawade et al } \\
\text { (2005) }\end{array}$ \\
\hline & $\gamma$-alumina fibers & Imazaquin & 80 & 1.6 & $\begin{array}{l}\text { Paul et al. } \\
\text { (2011) }\end{array}$ \\
\hline & $\begin{array}{l}\text { Mesoporous } \\
\text { Alumina } \\
\text { Nanoparticles }\end{array}$ & Lindane & - & 25.54 & $\begin{array}{l}\text { Derbalah et } \\
\text { al. (2015) }\end{array}$ \\
\hline & $\begin{array}{c}\text { Nanocrystalline } \\
\gamma \text {-alumina }\end{array}$ & Diazinon & 90 & - & $\begin{array}{c}\text { Armaghan } \\
\text { and Amini } \\
\text { (2012) }\end{array}$ \\
\hline & $\begin{array}{c}\text { Microesferas } \\
\text { huecas de } \\
\text { alumina }\end{array}$ & p-nitrophenol & - & 217.4 & $\begin{array}{l}\text { Zhou et al. } \\
\text { (2013) }\end{array}$ \\
\hline & $\gamma$-alumina fibers & Alachlor & 100 & 1 & $\begin{array}{l}\text { Paul et al. } \\
\text { (2011) }\end{array}$ \\
\hline & $\begin{array}{l}\text { Nanocrystalline } \\
\gamma \text {-alúmina }\end{array}$ & Fenitrothion & 57 & - & $\begin{array}{l}\text { Armaghan } \\
\text { and Amini } \\
\text { (2012) }\end{array}$ \\
\hline & $\begin{array}{l}\text { Mesoporous } \\
\text { alumina } \\
\text { aluminum } \\
\text { phosphate }\end{array}$ & Pentachlorophe] & 58.3 & 3 to 7 & $\begin{array}{l}\text { Danis et al. } \\
\text { (1998) }\end{array}$ \\
\hline & $\begin{array}{c}\text { Alumina modified } \\
\text { with SDS }\end{array}$ & Phenantrene & 80 & - & Jain (1999) \\
\hline & $\begin{array}{l}\text { Mesoporous } \\
\text { alumina } \\
\text { aluminum } \\
\text { phosphate }\end{array}$ & $\begin{array}{l}\text { 2,4,6- } \\
\text { trichlorophenol }\end{array}$ & 27.1 & 3 to 7 & $\begin{array}{c}\text { Danis et al. } \\
\text { (1998) }\end{array}$ \\
\hline & $\mathrm{Al}_{2} \mathrm{O}_{3}$ & $\begin{array}{l}\text { Orto-Nitro- } \\
\text { Phenol }\end{array}$ & - & 6.333 & $\begin{array}{c}\text { Aazza et al. } \\
\text { (2017) }\end{array}$ \\
\hline & $\gamma$-alumina & $\begin{array}{c}\text { Meta- } \\
\text { nitrophenol }\end{array}$ & - & 2 to 3 & $\begin{array}{c}\text { Aazza et al. } \\
\text { (2018) }\end{array}$ \\
\hline & $\mathrm{HDTMA}^{+} / \mathrm{Al}_{2} \mathrm{O}_{3}$ & $\begin{array}{c}\text { Meta- } \\
\text { nitrophenol }\end{array}$ & - & 8 to 9 & $\begin{array}{c}\text { Aazza et al. } \\
\text { (2018) }\end{array}$ \\
\hline & $\begin{array}{l}\text { Mesoporous } \\
\text { alumina } \\
\text { aluminum } \\
\text { phosphate }\end{array}$ & $\begin{array}{c}\text { 2,4- } \\
\text { dichlorophenol }\end{array}$ & 14.8 & 3 to 7 & $\begin{array}{l}\text { Danis et al. } \\
\text { (1998) }\end{array}$ \\
\hline & HDTMA $/ \mathrm{Al}_{2} \mathrm{O}_{3}$ & $\begin{array}{l}\text { Orto-Nitro- } \\
\text { Phenol }\end{array}$ & - & 7.294 & $\begin{array}{c}\text { Aazza et al. } \\
\text { (2017) }\end{array}$ \\
\hline
\end{tabular}




\begin{tabular}{|c|c|c|c|c|c|}
\hline \multicolumn{6}{|c|}{ Table 2 continued } \\
\hline \multirow[t]{4}{*}{$\begin{array}{l}\text { Pharmaceutica } \\
\text { compounds }\end{array}$} & $\begin{array}{c}\text { Poly } \\
\text { (2-acrylamide-2- } \\
\text { methylpropane } \\
\text { sulfonic acid) on } \\
\text { alumina } \\
\text { nanoparticles }\end{array}$ & Ciprofloxacin & 95 & 2.14 & $\begin{array}{l}\text { Dao et al. } \\
\text { (2020) }\end{array}$ \\
\hline & $\begin{array}{l}\text { Silica-alumina } \\
\text { compound }\end{array}$ & Metformin & 95 & 46 & $\begin{array}{l}\text { Alnajjar et al. } \\
\text { (2019) }\end{array}$ \\
\hline & $\begin{array}{c}\text { Alumina Modified } \\
\text { with Surfactant } \\
\text { (SDS) }\end{array}$ & Oxytetracycline & 97 & 143 & $\begin{array}{c}\text { Pham et al. } \\
\text { (2019) }\end{array}$ \\
\hline & $\begin{array}{l}\text { Activated Alumina } \\
\text { doped with Iron }\end{array}$ & Norfloxacin & 90.14 & - & $\begin{array}{l}\text { W. Liu et al. } \\
\text { (2011) }\end{array}$ \\
\hline
\end{tabular}

\section{CONCLUSIONS AND RECOMMENDATIONS}

Alumina presented high removal percentages for emerging pollutants in the literature reviewed, most of these adsorbents showing removal percentages greater than $80 \%$, which is why it can be considered a good adsorbent alternative for adsorption. Desorption experiments in the literature confirmed that the spent adsorbent can be successfully regenerated and can be efficiently reused with almost the same sorption capacity, reducing the cost of treatment. It is also important to mention that the location of the specific polluted effluents must be known since they can cause a change in the aquatic environments and to be able to give them the appropriate treatment.

\section{ACKNOWLEDGEMENTS}

Thanks to Universidad Autónoma de Ciudad Juárez and CONACYT.

\section{REFERENCES}

Aazza, M., Ahlafi, H., Moussout, H., \& Maghat, H. (2017). Ortho-Nitro-Phenol adsorption onto alumina and surfactant modified alumina: kinetic, isotherm and mechanism. Journal of Environmental Chemical Engineering, 5(4), 3418-3428. Retrieved from https://dx.doi .org/10.1016/j.jece.2017.06.051 10.1016/j.jece.2017.06.051

Aazza, M., Ahlafi, H., Moussout, H., \& Maghat, H. (2018). Adsorption of metha-nitrophenol onto alumina and HDTMA modified alumina: Kinetic, isotherm and mechanism investigations. Journal of Molecular Liquids, 268, 587-597. Retrieved from https://dx.doi.org/ 10.1016/j.molliq.2018.07.095 10.1016/j.molliq.2018.07.095

Adak, A., Bandyopadhyay, M., \& Pal, A. (2005). Removal of crystal violet dye from wastewater by surfactant-modified alumina. Separation and Purification Technology, 44(2), 139-144. Retrieved from https://dx.doi.org/10.1016/j.seppur.2005.01.002 10.1016/ j.seppur.2005.01.002

Ahmad, R., \& Kumar, R. (2010). Adsorption of Amaranth Dye onto Alumina Reinforced Polystyrene. CLEAN - Soil, Air, Water, 39(1), 74-82. 
Alnajjar, M., Hethnawi, A., Nafie, G., Hassan, A., Vitale, G., \& Nassar, N. N. (2019). Silica-alumina composite as an effective adsorbent for the removal of metformin from water. Journal of Environmental Chemical Engineering, 7(3), 102994-102994. Retrieved from https:// dx.doi.org/10.1016/j.jece.2019.102994 10.1016/j.jece.2019.102994

\&amp; Metcalf, \& Eddy. (2003). Wastewater Engineering: Treatment and Reuse (4ta ed.). In . E. A. Jones (Ed.), Wastewater Engineering: Treatment and Reuse. McGraw-Hill.

An, C., Mcbean, E., Huang, G., Yao, Y., Zhang, P., Chen, X., \& Li, X. (2016). Multi-soillayeringsystems for wastewater treatment in small and remote communities. J.Environ. Inform. $P, 131-144$.

An, C., Yang, S., Huang, G., Zhao, S., Zhang, P., \& Yao, Y. (2016). Removal of sulfonated humic acid from aqueous phase by modified coal fly ash waste: Equilibrium and kinetic adsorption studies. Fuel, 165, 264-271. Retrieved from https://dx.doi.org/10.1016/j.fuel.2015.10 .069 10.1016/j.fuel.2015.10.069

Armaghan, M., \& Amini, M. M. (2012). Adsorption of diazinon and fenitrothion on nanocrystalline alumina from non-polar solvent. Colloid Journal, 74(4), 427-433. Retrieved from https://dx.doi.org/10.1134/s1061933x12040047 10.1134/s1061933x12040047

Ashby, M. F., \& Jones, D. R. (2008). Introducción a las propiedades, las aplicaciones y el diseño. Materiales para ingeniería.

Ashfaq, M., Khan, K. N., Rasool, S., Mustafa, G., Saif-Ur-Rehman, M., Nazar, M. F., Sun, Q., \& Yu, C.P. (2016). Occurrence and ecological risk assessment of fluoroquinolone antibiotics in hospital waste of Lahore, Pakistan. Environmental Toxicology and Pharmacology, 42, 16-22. Retrieved from https://dx.doi.org/10.1016/j.etap.2015.12.015 10.1016/j.etap .2015 .12 .015

Banerjee, S., Dubey, S., Gautam, R. K., Chattopadhyaya, M. C., \& Sharma, Y. C. (2017). Adsorption characteristics of alumina nanoparticles for the removal of hazardous dye, Orange $\mathrm{G}$ from aqueous solutions. Arabian Journal of Chemistry.

Bansal, R. C., \& Goyal, M. (2005). Taylor \& Francis Group. In Activated carbon adsorption. USA: Taylor \& Francis Group.

Boumaza, A., Favaro, L., Lédion, J., Sattonnay, G., Brubach, J. B., Berthet, P., Huntz, A. M., Roy, P., \& Tétot, R. (2009). Transition alumina phases induced by heat treatment of boehmite: An X-ray diffraction and infrared spectroscopy study. Journal of Solid State Chemistry, 182(5), 1171-1176. Retrieved from https://dx.doi.org/10.1016/j.jssc.2009.02.006 10 .1016/j.jssc.2009.02.006

Brage, A. G. (Ed.). (2002). Calidad y tratamiento del agua: Manual de suministros de agua comunitaria. American Water Works Association.

Cardon, D. (2010). Natural dyes, our global heritage of colours. Textile Society of America, $6(9)$.

Chu, T., Nguyen, N., Vu, T., Dao, T., Dinh, L., Nguyen, H., \& Pham, T. (2019). Synthesis, Characterization, and Modification of Alumina Nanoparticles for Cationic Dye Removal. Materials, 12(3), 450-450.

Clemente, A., Rubio, C., Arrieta, E., Lenin, P., Mesa, G., \& Antonio. (2013). Procesos de tratamiento de aguas residuales para la eliminación de contaminantes orgánicos emergentes. Revista Ambiente \& Água, 8(3), 93-103.

Damià, B. (2003). Emerging pollutants in water analysis. Emerging pollutants in water analysis, 22, 0-0.

Danis, T. G., Albanis, T. A., Petrakis, D. E., \& Pomonis, P. J. (1998). Removal of chlorinated phenols from aqueous solutions by adsorption on alumina pillared clays and mesoporous alumina aluminum phosphates. Water Research, 32(2), 295-302. 
Retrieved from https://dx.doi.org/10.1016/s0043-1354(97)00206-6 10.1016/s0043 -1354(97)00206-6

Dao, T. H., Vu, T. Q. M., Nguyen, N. T., Pham, T. T., Nguyen, T. L., Yusa, S., \& Pham, T. D. (2020). Adsorption Characteristics of Synthesized Polyelectrolytes onto Alumina Nanoparticles and their Application in Antibiotic Removal. Langmuir.

Das, A. K., Saha, S., Pal, A., \& Maji, S. K. (2009). Surfactant-modified alumina: An efficient adsorbent for malachite green removal from water environment. Journal of Environmental Science and Health, Part A, 44(9), 896-905. Retrieved from https://dx.doi.org/ $10.1080 / 10934520902958708$ 10.1080/10934520902958708

Daughton, C. G., \& Ternes, T. A. (1999). Pharmaceuticals and personal care products in the environment: agents of subtle change? (Vol. 107). Environmental Health Perspectives. Retrieved from https://dx.doi.org/10.1289/ehp.99107s6907 10.1289/ehp $.99107 \mathrm{~s} 6907$

Derbalah, A., El-Safty, S. A., Shenashen, M. A., \& AbdelGhany, N. A. (2015). Mesoporous Alumina Nanoparticles as Host Tunnel-like Pores for Removal and Recovery of Insecticides from Environmental Samples. ChemPlusChem, 80(7), 1119-1126. Retrieved from https://dx.doi.org/10.1002/cplu.201500098 10.1002/cplu.201500098

Ebadollahzadeh, H., \& Zabihi, M. (2020). Competitive adsorption of methylene blue and $\mathrm{Pb}$ (II) ions on the nano-magnetic activated carbon and alumina. Materials Chemistry and Physics, 248, 122893-122893. Retrieved from https://dx.doi.org/10.1016/ j.matchemphys.2020.122893 10.1016/j.matchemphys.2020.122893

Eckhard, W. (2012). Adsorption Technology in Water Treatment Fundamentals, Processes, and Modeling. Adsorption Technology in Water Treatment Fundamentals, Processes, and Modeling.

Estadísticas del agua en México. (2014). Comisión Nacional del Agua.

Fumey, B., Weber, R., Gantenbein, P., Daguenet-Frick, X., Williamson, T., \& Dorer, V. (2014). Development of a Closed Sorption Heat Storage Prototype. Energy Procedia, 46, 134-141. Retrieved from https://dx.doi.org/10.1016/j.egypro.2014.01.166 10.1016/ j.egypro.2014.01.166

Gawade, A. S., Vanjara, A. K., \& Sawant, M. R. (2005). Removal of herbicide from water with sodium chloride using surfactant treated alumina for wastewater treatment. Separation and Purification Technology, 41(1), 65-71. Retrieved from https://dx.doi.org/ 10.1016/j.seppur.2004.04.005 10.1016/j.seppur.2004.04.005

Gracia-Lor, E., Sancho, J. V., \& Hernández, F. (2011). Multi-class determination of around 50 pharmaceuticals, including 26 antibiotics, in environmental and wastewater samples by ultra-high performance liquid chromatography-tandem mass spectrometry. Journal of Chromatography A, 1218(16), 2264-2275. Retrieved from https://dx.doi.org/ 10.1016/j.chroma.2011.02.026 10.1016/j.chroma.2011.02.026

Hasan, M., Ahmad, A. L., \& Hameed, B. H. (2008). Adsorption of reactive dye onto cross-linked chitosan/oil palm ash composite beads. Chemical Engineering Journal, 136(2-3), 164172. Retrieved from https://dx.doi.org/10.1016/j.cej.2007.03.038 10.1016/j.cej.2007 .03 .038

Huerta, B., Jakimska, A., Llorca, M., Ruhí, A., Margoutidis, G., Acuña, V., Sabater, S., RodriguezMozaz, S., \& Barcelò, D. (2015). Development of an extraction and purification method for the determination of multi-class pharmaceuticals and endocrine disruptors in freshwater invertebrates. Talanta, 132, 373-381. Retrieved from https://dx.doi.org/ 10.1016/j.talanta.2014.09.017 10.1016/j.talanta.2014.09.017

Hughes, S. R., Kay, P., \& Brown, L. E. (2013). Global Synthesis and Critical Evaluation of 
Pharmaceutical Data Sets Collected from River Systems. Environmental Science \& Technology, 47(2), 661-677. Retrieved from https://dx.doi.org/10.1021/es3030148 10 $.1021 / \mathrm{es} 3030148$

Jain, P. (1999). Reusable adsorbents for dilute solution separation 3. Sorption dynamics of phenanthrene on surfactant-modified alumina. Separation and Purification Technology, 17(1), 21-30. Retrieved from https://dx.doi.org/10.1016/s1383-5866(99)00018 -0 10.1016/s1383-5866(99)00018-0

Joss, A., Siegrist, H., \& Ternes, T. A. (2008). Are we about to upgrade wastewater treatment for removing organic micropollutants? Water Science and Technology, 57(2), 251-255. Retrieved from https://dx.doi.org/10.2166/wst.2008.825 10.2166/wst.2008.825

Kannan, C., Sundaram, T., \& Palvannan, T. (2008). Environmentally stable adsorbent of tetrahedral silica and non-tetrahedral alumina for removal and recovery of malachite green dye from aqueous solution. Journal of Hazardous Materials, 157(1), 137-145. Retrieved from https://dx.doi.org/10.1016/j.jhazmat.2007.12.116 10.1016/j.jhazmat.2007.12 .116

Karageorgis, A. P., Nikolaidis, N. P., Karamanos, H., \& Skoulikidis, N. (2003). Water and sediment quality assessment of the Axios River and its coastal environment. Continental Shelf Research, 23(17-19), 1929-1944. Retrieved from https://dx.doi.org/10.1016/ j.csr.2003.06.009 10.1016/j.csr.2003.06.009

Khang, D., Liu-Snyder, P., Pareta, R., Lu, J., \& Webster, T. J. (2009). Reduced responses of macrophages on nanometer surface features of altered alumina crystalline phases. Acta Biomaterialia, 5(5), 1425-1432. Retrieved from https://dx.doi.org/10.1016/j.actbio .2009.01.031 10.1016/j.actbio.2009.01.031

Kordouli, E., Bourikas, K., Lycourghiotis, A., \& Kordulis, C. (2015). The mechanism of azo-dyes adsorption on the titanium dioxide surface and their photocatalytic degradation over samples with various anatase/rutile ratios. Catalysis Today, 252, 128-135. Retrieved from https://dx.doi.org/10.1016/j.cattod.2014.09.010 10.1016/j.cattod.2014.09.010

Kurtan, U., Amir, M., Ylldız, A., \& Baykal, A. (2016). Synthesis of magnetically recyclable MnFe $204 @$ @iO $2 @ A g$ nanocatalyst: Its high catalytic performances for azo dyes and nitro compounds reduction. Applied Surface Science, 376, 16-25. Retrieved from https://dx .doi.org/10.1016/j.apsusc.2016.02.120 10.1016/j.apsusc.2016.02.120

Lesmana, S. O., Febriana, N., Soetaredjo, F. E., Sunarso, J., \& Ismadji, S. (2009). Studies on potential applications of biomass for the separation of heavy metals from water and wastewater. Biochemical Engineering Journal, 44(1), 19-41. Retrieved from https:// dx.doi.org/10.1016/j.bej.2008.12.009 10.1016/j.bej.2008.12.009

Liu, W., Zhang, J., Zhang, C., \& Ren, L. (2011). Sorption of norfloxacin by lotus stalk-based activated carbon and iron-doped activated alumina: Mechanisms, isotherms and kinetics. Chemical Engineering Journal, 171(2), 431-438.

Liu, X., Gong, W., Luo, J., Zou, C., Yang, Y., \& Yang, S. (2016). Selective adsorption of cationic dyes from aqueous solution by polyoxometalate-based metal-composite. Appl. Surf. Sci. $p, 517-524$.

López, R., \& Y, S. (2006). Síntesis metal orgánica de alfa-alúmina a partir de aluminio. Síntesis metal orgánica de alfa-alúmina a partir de aluminio. Tesis magistral.

Mahapatra, A., Mishra, B. G., \& Hota, G. (2013). Adsorptive removal of Congo red dye from wastewater by mixed iron oxide-alumina nanocomposites. Ceramics International, 39(5), 5443-5451. Retrieved from https://dx.doi.org/10.1016/j.ceramint.2012 .12 .052 10.1016/j.ceramint.2012.12.052

Malakootian, M., Mansoorian, H. J., Hosseini, A., \& Khanjani, N. (2015). Evaluating the efficacy 
of alumina/carbon nanotube hybrid adsorbents in removing Azo Reactive Red 198 and Blue 19 dyes from aqueous solutions. Process Safety and Environmental Protection, 96, 125-137. Retrieved from https://dx.doi.org/10.1016/j.psep.2015.05.002 10.1016/j .psep.2015.05.002

Mercier, J. P., Zambelli, G., \& Kurz, W. (2002). Introduction to Materials Science . In Introduction to Materials Science. Elsevier.

Mishra, G., \& Tripathy, M. (1993). A critical review of the treatments for decolouration of textile effluent. Colourage, 40, 35-43.

Nadafi, K., Vosoughi, M., Asadi, A., Borna, M. O., \& Shirmardi, M. (2014). Reactive Red 120 dye removal from aqueous solution by adsorption on nano-alumina. Journal of Water Chemistry and Technology, 36(3), 125-133. Retrieved from https://dx.doi.org/10.3103/ s1063455x14030059 10.3103/s1063455x14030059

Naganoma, T., \& Zagawa, Y. (2002). Compos Sci Technol. Compos Sci Technol, 62, 1187-1187.

Paul, B., Martens, W. N., \& Frost, R. L. (2011). Surface modification of alumina nanofibres for the selective adsorption of alachlor and imazaquin herbicides. Journal of Colloid and Interface Science, 360(1), 132-138. Retrieved from https://dx.doi.org/10.1016/j.jcis .2011.04.055 10.1016/j.jcis.2011.04.055

Petrie, B., Barden, R., \& Kasprzyk-Hordern, B. (2015). A review on emerging contaminants in wastewaters and the environment: Current knowledge, understudied areas and recommendations for future monitoring. Water Research, 72, 3-27. Retrieved from https://dx.doi.org/10.1016/j.watres.2014.08.053 10.1016/j.watres.2014.08.053

Pham, T. D., Tran, T. T., Le, V. A., Pham, T. T., Dao, T. H., \& Le, T. S. (2019). Adsorption characteristics of molecular oxytetracycline onto alumina particles: The role of surface modification with an anionic surfactant. Journal of Molecular Liquids, 110900-110900.

Pharmaceuticals in drinking-water. (n.d.). World Health Organization. (2012). Pharmaceuticals in drinking-water. World Health Organization.

Rane, N. R., Chandanshive, V. V., Khandare, R. V., Gholave, A. R., Yadav, S. R., \& Govindwar, S. P. (2014). Green remediation of textile dyes containing wastewater by Ipomoea hederifolia L. RSC Adv., 4, 36623-36632. Retrieved from https://dx.doi.org/10.1039/ c4ra06840h 10.1039/c4ra06840h

Renuka, N. K., Shijina, A. V., \& Praveen, A. K. (2012). Mesoporous $\gamma$-alumina nanoparticles: Synthesis, characterization and dye removal efficiency. Materials Letters, 82, 42-44. Retrieved from https://dx.doi.org/10.1016/j.matlet.2012.05.043 10.1016/j .matlet.2012.05.043

Richardson, S. D., \& Ternes, T. A. (2014). Water Analysis: Emerging Contaminants and Current Issues. Analytical Chemistry, 86(6), 2813-2848. Retrieved from https://dx.doi.org/10 .1021/ac500508t 10.1021/ac500508t

Rivera-Utrilla, J., Sánchez-Polo, M., Ángeles Ferro-García, M., Prados-Joya, G., \& OcampoPérez, R. (2013). Pharmaceuticals as emerging contaminants and their removal from water. A review (Vol. 93). Elsevier BV. Retrieved from https://dx.doi.org/10.1016/ j.chemosphere.2013.07.059 10.1016/j.chemosphere.2013.07.059

Ruhí, A., Acuña, V., Barceló, D., Huerta, B., Mor, J.-R., Rodríguez-Mozaz, S., \& Sabater, S. (2016). Bioaccumulation and trophic magnification of pharmaceuticals and endocrine disruptors in a Mediterranean river food web. Science of The Total Environment, 540, 250259. Retrieved from https://dx.doi.org/10.1016/j.scitotenv.2015.06.009 10.1016/j .scitotenv.2015.06.009

Sastre, R., Aza, S. D., \& Román, J. S. (2004). Biomateriales. In B. F. F. E. Ibérica \& S. L (Eds.), . Schwarzenbach, R. P., Escher, B. I., Fenner, K., Hofstetter, T. B., Johnson, C. A., Gunten, U. V., \& 
Wehrli, B. (2006). The challenge of micropollutants in aquatic systems. Science, 10721077.

Sebastian, K., Michael, M., \& Oskar, N. (2017). Polymer Chemistry. Springer. . Polymer Chemistry.

Sen, T. K., Afroze, S., \& Ang, H. M. (2011). Equilibrium, Kinetics and Mechanism of Removal of Methylene Blue from Aqueous Solution by Adsorption onto Pine Cone Biomass of Pinus radiata. Water, Air, \& Soil Pollution, 218(1-4), 499-515. Retrieved from https:// dx.doi.org/10.1007/s11270-010-0663-y 10.1007/s11270-010-0663-y

Smith, W. (2009). Fundamentos de la ciencia e ingeniería de materiales. Fundamentos de la ciencia e ingeniería de materiales.

Smith, W., \& Hashemi, J. (2006). Fundamentos de la ciencia e ingeniería de materiales (4th edición. ed.). Mc Graw Hill. Fundamentos de la ciencia e ingeniería de materiales.

Wawrzkiewicz, M., Wiśniewska, M., Gun'ko, V. M., \& Zarko, V. I. (2015). Adsorptive removal of acid, reactive and direct dyes from aqueous solutions and wastewater using mixed silica-alumina oxide. Powder Technology, 278, 306-315. Retrieved from https://dx.doi .org/10.1016/j.powtec.2015.03.035 10.1016/j.powtec.2015.03.035

Willmott, N., Nelson, G. J., \& G. (1998). The biotechnology approach to colour removal from textile effluent. J Soc Dyes Colour, 114, 38-41.

Yedla, S., \& Dikshit, A. K. (2005). Removal of Organochlorine Pesticide from Water Environment. Narosa Publushing House. Abatement of Pesticide Pollution: Removal of Organochlorine Pesticide from Water Environment.

Zacarías, V. H.-R., Machuca, M. A. V., Soto, J. L. M., Equihua, J. L. P., Cardona, A. A. V., Calvillo, M. D. L., \& González, J. V. (2017). Hidroquímica y contaminantes emergentes en aguas residuales urbano-industriales de Morelia, Michoacán, México. In Hidroquímica y contaminantes emergentes en aguas residuales urbano-industriales de Morelia (Vol. 33, pp. 221-235).

Zhang, W., Jiang, F., \& Ou, J. (2011). Global pesticide consumption and pollution: with China as a focus. Proceeding of the International Academy of Ecology and Environmental Sciences, $2,125-144$.

Zhou, J., Wang, L., Zhang, Z., \& Yu, J. (2013). Facile synthesis of alumina hollow microspheres via trisodium citrate-mediated hydrothermal process and their adsorption performances for p-nitrophenol from aqueous solutions. Journal of Colloid and Interface Science, 394, 509-514. 